\title{
Lesbian Spanners: A Re-appraisal of UK Consensual Sadomasochism Laws
}

\author{
Sarah Beresford ${ }^{1}$ (D)
}

Published online: 10 June 2016

(c) The Author(s) 2016. This article is published with open access at Springerlink.com

\begin{abstract}
There continues to be legal invisibility of lesbians as sexual beings; in particular, for those lesbians who engage in BDSM. A cursory glance at work both within and outside of the academy gives the impression of increased social and legal acceptability for those who engage in BDSM. However, I suggest that this acceptance is illusory and that instead, gay men who engage in BDSM experience increased legal supervision and increased invisibility for lesbians. These issues are examined in the context of two seemingly disparate legal events. The first is the 30 year anniversary of Operation Spanner and the second is the introduction of the Audiovisual Media Services Regulations 2014. Amongst other things, the 2014 Regulations criminalise the portrayal of female ejaculation (but not male). Given this criminalisation of certain kinds of female sexual pleasure, the potentiality to significantly adversely impact upon lesbians is clear. 2017 will be the 30 year anniversary of Operation Spanner and the subsequent focus has been primarily upon gay male BDSM. I speculate as to the possible legal reaction(s) to a lesbian 'spanner' BDSM event. I speculate as to the legal reactions to an all-female BDSM dungeon.
\end{abstract}

Keywords Lesbian · Law · BDSM · Operation Spanner

Sarah Beresford

s.beresford@lancaster.ac.uk

1 The Law School, Lancaster University, Lancaster LA1 4YN, UK 


\section{Introduction}

This article argues that there continues to be legal invisibility of lesbians as sexual beings and in particular, for those lesbians who engage in BDSM (bondage and discipline, sadism and masochism). This legal invisibility leads to a lack of legal clarity and uncertainty for lesbians who engage in BDSM. These issues are examined in the context of two seemingly disparate legal events, separated by nearly 30 years. The first is Operation Spanner, the name given to a police investigation in 1987, which was prompted by the chance finding of videotapes of consensual BDSM activities. 2017 will be the 30 year anniversary of Operation Spanner. The men were arrested and charged, with a range of offences, primarily under the Offences Against the Person Act 1861. The second of the legal events, is the Audiovisual Media Services Regulations 2014. These Regulations apply to all Video on Demand ( $\mathrm{ODD}$ ), content created in the UK and amongst other things, they criminalise the portrayal of female ejaculation (but not male). Given that the portrayal of certain kinds of female sexual pleasure is now a criminal offence, this has the potentiality to significantly adversely impact upon lesbians who film the BDSM they engage in. The subsequent Statutory activity; case law and academic attention since Operation Spanner, have focussed primarily upon gay male BDSM and how this activity is discriminated against in comparison to heterosexual BDSM. It is clear from $R v$ Brown [1994] 1 AC 212 (still the leading authority on this issue), and subsequent case law, that for gay men, it is not legally possible to consent to sadomasochistic harm. Much of the literature that deals with this issue correctly points to an exclusionary; demonizing; criminalising and discriminating legal approach to gay male BDSM. In the 30 years of analysis since Operation Spanner, there has been a significant amount of analysis on the subject and a significant amount a work done on the repercussions of Spanner, of $R \vee$ Brown, and in the area of consent to BDSM. However, the vast majority of this literature has either expressly or implicitly concerned gay men or heterosexual women. Moran, for example comments that $R$ v Brown works to "re-criminalize sexual relations between gay men" (Moran 1996: 190). There has not been a similar volume of scholastic research conducted which has examined these issues specifically from a lesbian perspective. This article seeks to re-balance this unequal focus. In so doing, I start with locating the relative legal invisibility of lesbians who engage in BDSM including an examination of the socio-legal consequences of invisibility for women who engage in BDSM with other women. Given that "BDSM appears to be on the cusp of a new understanding" (Chatterjee 2012: 739), I then develop this into describing and analysing how the law has developed to apply to women who engage in BDSM, with other women. ${ }^{1}$ I ask how lesbians who engage in BDSM experience the legal gaze and what might be some of the consequences might be for lesbians who engage in BDSM? What should be the response to these developments

\footnotetext{
1 There is no commonly accepted definition of what constitutes BDSM behaviour. Certain characteristics seem to be common to the practice, including negotiated, consensual infliction of pain experienced by the parties as pleasurable, and by using fantasy and role-playing and fetishistic elements, such as dress and scenery. For an excellent feminist critique of the potential criminalisation of commercial BDSM, (see Cowan 2012).
} 
regarding the legal specificity of lesbian BDSM? I speculate as to the possible legal reaction(s) to a fictitious police raid on a lesbian only BDSM event in which the activities were filmed and the results posted as VoD. How might the law react if the people in the BDSM dungeon are all women? ${ }^{2}$ Would they be treated the same as the men in $R v$ Brown and what might that tell us about the operation of legal norms? My aim is to advance an important perspective; namely, that of a more nuanced approach to lesbian sexual citizenship. I conclude by suggesting that the lesbians in the dungeon will be treated by law as women (not specifically lesbians), who have offended against the criminal law and their expected gender performativity. I further suggest that lesbian sex acts are investigated and prosecuted etc., not because they are lesbians sex acts but because of the perceived gender deviance.

\section{Invisibility of Lesbians}

When the Centre for Disease Control in America was asked why it had not carried out any research on woman-to-woman transmission of HIV, the reply was that "Lesbians don't have much sex" (Smith 1992: 207). This is an illustration that lesbian invisibility is not just due to lesbians as subjects being invisible, but also that they are invisible as sexual subjects. Given that in the past lesbians have been "deprived of a sexual language by a predominantly male culture" (Plummer 1992: xvii), how could the discourse post $R v$ Brown be viewed from a lesbian perspective? Does the introduction of the Audiovisual Media Services Regulations 2014 provide yet more evidence that lesbian sexuality is legally invisible and irrelevant? Lesbian identities and experiences have a long cultural history, although unfortunately, much of that history has been undocumented, concealed or invisible (Donoghue 1993: Faderman 1985). In a legal context, those identities and experiences have only a recent visible history, having been rendered invisible by, and displaced from, legal culture. Indeed, the first time that the word 'lesbian' appeared in a British statute was in relation to the notorious s.28 of the Local Government Act 1988. Thus, for many years, the identity of the lesbian was an invisible identity, "for most of the nineteenth century in England, the word 'lesbian' was virtually unknown" (Zimmerman 2000). It still is. I am not of course, suggesting that lesbians should be equally demonised and criminalised in a race to the bottom (forgive the pun), with gay men, but it is also clear that "exclusion of lesbian sexuality from official disclosure on homosexuality constitutes a thoroughly anti-lesbian strategy" (Smith 1992: 210). Consequently, as Smyth argues, lesbians should work to ensure that:

We are not simply tagged on to equality campaigns in connection with procreation and the family ... we have never had the safety to take the same public space for sexual adventures as gay men, yet we solicit, procure, indecently assault and fuck each other in SM scenarios and want the right to be

\footnotetext{
2 It might be that in a room full of women engaging in BDSM, not all of them would identify as lesbian, however, I am assuming that (a) of those that do identify a sexual orientation, the majority will identify as lesbian and (b) that the law will assume a lesbian identity of the women.
} 
acknowledged for our sex and sexuality, just as gay men rightly demand (Smyth 1990: 64).

Smyth's concerns echo a tendency in the literature to use a discourse which speaks of lesbians as if they belong in the category of 'homosexual', which is an implicitly male construct. Much of the literature which discusses attitudes towards homosexuality impliedly uses the category of homosexual to include lesbians. However, this is problematic as although the term 'homosexual' or 'gay' might be intended as a gender-neutral term, "it functions more often than not as a masculine signifier" (Thompson 2002: 34-35). The implications of this conflation mean that lesbians are rendered 'invisible as homosexuals while simultaneously included in the category for the purposes of regulating identity (Thompson 2002: 34-35).

In writing this article, there were several methodological impediments and concerns. The first was in locating relevant material and I was not surprised by this difficulty. Numerous searches across several platforms turned up sources which were overwhelmingly 'lesbianandgaymen' (as if it is one word); written from a gay (male); or (heterosexual) feminist perspective. There were few articles which dealt solely with lesbians, the few that did so were mainly about lesbians becoming mothers or losing/gaining access to their children or fertility services resulting in the "legal and familial discourse became the main ones through which lesbianism was expressed" (Shadmi 2008: 315). Examples of the few exceptions to this are Hornsby and Calhoun (Calhoun 1995). Hornsby, for example, argues that within feminism, lesbian sadomasochism, if thought of at all, is thought as antithetical to feminism (Hornsby 2008: 61-72). Deckha, for example, admits to excluding lesbian BDSM as including lesbian BDSM made her theories too convoluted to see. Deckha suggests that heterosexual women who engage in BDSM have a "unique symbolic meaning of heterosexual $\mathrm{S} / \mathrm{M}$ for feminists seeking to resist male dominance and exploitation" (Deckha 2007: 427). This suggests that lesbians are not subject to male dominance and exploitation. Boryczka, in exploring how virtue and vice have been used as a discursive political tool to create a class of suspect citizens, argues that lesbians who engaged in BDSM practices have been accused of replicating "the very masculine power dynamics used to perpetuate women's oppression" (Boryczka 2012: 108).

These methodological constraints and concerns were as frustrating as they were illuminating. In order to write about the extent to which lesbians are viewed as sexual beings, then by necessity, 'the lesbian' is required to exist as a subject. Furthermore, in order to write about lesbian BDSM, she must be considered as a sexual subject. The relative fruitlessness of my search clearly indicates that within the academy and within the criminal law, lesbians do not occupy (much) discursive space and are majoratively, not considered sexual beings. I contend that the lesbian must, and needs, to exist as a visible discursive category as otherwise she is conceptualised as existing somewhere between a variant of a heterosexual women or a gay man. If, as post structuralism and queer theory suggests, there is no subject, the lesbian consequently disappears and becomes subsumed and compromised so consistently and so effectively as to blink out of experiential existence. How then, might this conundrum be tackled? One possible solution to post-structuralist 
disappearance is to accept that whilst identities can be thought of as fluid, variable, shifting, changing and that this identity construction is also "arbitrary, unstable and exclusionary", these identities can simultaneously exist (Plummer 2002: 237). Whilst therefore, lesbian identity might very well be an identity that is constantly in flux and "in progress" (Hall 1996: 6), it is also an identity that can necessarily, and effectively, provide a site of resistance to dominant normative hetero-patriarchal identity. What is important however is that it should be a visible identity.

Visibility however, is not unproblematic, and the problematic nature of lesbian visibility stems from two main, but interrelated issues. The first relates to the idea of sexuality being both private and public. It is not unreasonable to suggest that most individuals (whether BDSM practitioners or not), wish to keep their sex lives private. However, those individuals who are positioned by law as 'deviant', often simultaneously want legal (and therefore) public recognition of the 'right to a private life'. The notion of wanting a 'right' to privacy has its origins in individuals revisiting the intrusion of the State 'abuses of governmental authority' (Wood and Lodge 2013: 650). This right however, has not been extended to those who are considered by the State to be 'sexually deviant', meaning that 'many of the same people who seek to politicise what has been too heavily privatised, also wish to affirm a 'right to privacy' (Weeks 1992). For lesbians, this entails the duality of desiring to occupy definitive discursive space as a visible lesbian, and simultaneously desiring to maintain a 'private life'. Arguably therefore, this duality of desire leads to an occupation of "negative semantic space" (Frye 1983: 173). The subordination of lesbians by the epistemic combined with the desire to have a private sex life, contributes to lesbian invisibility. The introduction of the Audiovisual Media Services Regulations 2014 is an illustration of lesbians occupying negative sematic space (they are not mentioned in the Regulations), but simultaneously directly affected by the Regulations. They are both visible and invisible. The second issue relates to a nervousness some lesbians of publically acknowledging any sexuality which was (and is), regarded as 'deviant', leading to a conformity to heteronormative values of sexual expression. Thus the rendering of lesbians as invisible can sometimes come from lesbians themselves. As explained by Pilcher and Whelehan, "so nervous were early radical lesbian feminists of 'miming' heterosexuality in any way, there was a virtual taboo until the late 1980s on the discussion of practices or identities which were thought to reflect back to heterosexuality-for example, butch and femme or SM (sadomasochism)" (Pilcher and Whelehan 2004: 71). Further examples include a refusal by the Lesbian Archive in London to refuse to stock material relating to "the lesbian s/m culture" (Plummer 1992: 211). ${ }^{3}$ Exclusion has also come from other feminists, for example, the first president of the American pressure group, National Organisation for Women (NOW), stated that lesbian issues were not "central to feminist concerns and that lesbians would put the movement in jeopardy by coupling feminist with sexual deviants" (Seidman et al. 2006: 490). Part of the reason for this invisibility is that BDSM is regarded as violence, not sex; further, that the concepts of 'sex'; 'violence' and BDSM are male.

\footnotetext{
3 The Lesbian Archives Collective in London was transferred to Glasgow Women's Library in 1995.
} 


\section{Violence Not Sex?}

Whilst I maintain that it is necessary to maintain a discursive space of 'lesbian', I am also aware that it is necessary to continue to resist the operation of normative heterosexual discourse upon the lesbian subject. The Spanner case is illustrative of the law's desire to categorise BDSM as violence, not sex (Bell and Valentine 1995: 284), indeed, according to Lord Templeman "society is entitled and bound to protect itself against a cult of violence" ( $R v$ Brown: 84$)$. It is not just the judges who express such concerns. For some, BDSM merely reproduces the violence that marks patriarchy's hold over the performance of femininity (Hopple 1996). For others, sexuality, when expressed in a lesbian BDSM context is a cultural production and a "variation of violence against women which apes the worst of patriarchy" (O'Sullivan 1999: 101). BDSM is therefore illustrative of two significant concerns in law and society; how to regulate and control sex and violence. These concerns have important consequences therefore, when it comes to a legal gaze which constructs violence committed by women as different from the violence committed by men. Further, the expression of female sexuality receives different legal attention than does the expression of male sexuality. Women, who therefore engage in an activity which to them is sexual, but to law is violence, may very well be subjected to different normative control. In $R$ v Brown, the disciplinary operation of law's moral disapprobation was directed primarily at protecting society from the 'violence' of possible HIV infection and was therefore directed at their sexual behaviour, not their sexual orientation (Sedgwick 1990). Similarly, the Audiovisual Media Services Regulations 2014 were introduced in order to protect those who are deemed vulnerable (in this instance, minors), from accessing material which might be considered 'harmful.' This justification echoes Cowan's argument that it is the notion of vulnerability which is increasingly relied upon to justify enhanced criminal penalties (Cowan 2012). Further, the justification for section 63 of the Criminal Justice and Immigration Act 2008, was, according the Government, due to concerns regarding the 'sexual torture' offences committed in $R v$ Brown.

Given this, it is not unreasonable to argue that those male bodies who engage in BDSM are treated differently by law and society than female bodies who engage in BDSM. In this context therefore, the performance of sex is male and the expression of sexuality in the form of BDSM is also male.

It might be helpful at this juncture to explore what is meant by this statement. To state that most BDSM is male is to argue that it is formed by, and through, the lens of patriarchal male desire. As mentioned above, the leading case in this area is still the House of Lords decision in $R v$ Brown, Lucas, Jaggard, Laskey and Carter, [1993] 2 All ER 75 which situated sadomasochistic activities as constituting unlawful assault. The facts are well known; five gay men were charged with assault occasioning actual bodily harm contrary to section 47 of the Offences Against the Person Act 1861, and unlawful wounding contrary to section 20 of the same Act. The question of law which their Lordships thought was of general public importance was; 
Where A wounds or assaults B occasioning him actual bodily harm in the course of a sadomasochistic encounter, does the prosecution have to prove lack of consent on the part of B before they can establish A's guilt under section 20 or section 47 of the Offences Against the person Act 1861?' (R v Brown: 559).

By a split decision (three to two), the House of Lords upheld the original conviction stating that "it would not be in the public interest that deliberate infliction of actual bodily harm during the course of homosexual sadomasochistic activities should be held to be lawful." ( $R v$ Brown per Jauncey LJ: 574). Although Lord Templeman acknowledged that consent can be a defence to infliction of bodily harm during activities such as sporting events, he was quite clear that consensual BDSM activity was not something that could be consented to. The case was reviewed by the European Court of Human Rights in 1997 in Laskey, Jaggard and Brown v United Kingdom (1997) 24 EHRR 39. The Court held that whilst the law prohibiting consensual sadomasochistic activity did violate the right to respect for one's private life under Article 8(1), the interference was justified as necessary in a democratic society for the protection of health and the interests of others. In addition, the Court also stated that national governments were entitled to criminalise consensual infliction of harm. The European Court accepted that although the acts described in this case could be considered consensual, a prosecution was justified and did not constitute a violation of the defendants' private life because the "sadomasochistic activities involved a significant degree of injury or wounding which could not be characterised as trifling or transient". As I point out later, this runs contrary to John Stuart Mills' argument that there can be no state interference or criminal repercussions because there has been no 'violation of a person's right to autonomous self-determination', as long as 'real' consent is given.

The literature critiquing $R \mathrm{v}$ Brown written from a gay male (and arguably a patriarchal perspective), has been extensive in the intervening years. Stychin for example, argues that $R \mathrm{v}$ Brown is a good example of how the law 'pathologises gay male sexuality'. Whilst it is relatively straightforward to find literature about $R v$ Brown and BDSM from a gay male perspective (be it negative or positive), it is not so straightforward to find lesbians anywhere within mainstream literature, let alone from a BDSM perspective. One might argue that the 'standard' undergraduate texts books might provide a reasonable overview of the extent to which lesbian existence is acknowledged. For example, in Herring's Criminal Law: Text, Cases, and Materials (Herring 2014), there are seven uses of the word 'homosexual' compared to the word "lesbian which is used once and simply states 'lesbian sexual behaviour has not been the subject of specific prohibition under the criminal law." (Herring 2014: 3). In Herring's Criminal Law (Herring 2013), there are two instances where the word 'homosexual' is used and zero for 'lesbian'. In Smith and Hogan's Criminal law (Ormerod 2011) the word 'homosexual' is used eleven times; the word 'gay' is used five times and not at all for lesbian. In Criminal Law by Than and Heaton (de Than and Heaton 2013), the word homosexual is used five times; gay is used once and lesbian zero. Similar treatment is found in Michael Allen's Textbook on Criminal Law (Allen 2013), where there are zero references to lesbian; zero for 
gay and eight for homosexual. In Simester and Sullivan's Criminal Law: Theory and Doctrine (Simester and Spencer 2013), there are six references to homosexual; three for gay and zero for lesbian. A more socio-legal book such as Quick, Lacey and Wells' Reconstructing Criminal Law, never the less however makes zero references to lesbians in the index; 13 references to 'homosexuality', and zero for 'gay'. This adds up to a total of 52 references for 'homosexual/homosexuality'; 9 for 'gay' and I for 'lesbian'. Other books which have contributed in significant ways to the debates surrounding gay men and homosexuality include one of the first books in English to give extensive coverage of gay men and the law; Crane's Gays and the Law, ${ }^{4}$ which focused on gay men due to 'lesbians' relative invisibility under English law.' (Murphy 2000). Moran's excellent book The Homosexual(ity) of Law (Moran 1996) represented an important intervention in the scholastic field. It deals almost exclusively with gay men. Carl Stychin's Law's Desire: Sexuality and the Limits of Justice (Stychin 1995), contains three references to lesbians in the index, but only one of these three references actually specifically addresses lesbians (as opposed to 'lesbians and gay men'), in the main body of the text (Stychin 1995: 142). The recently published Consultation Paper by the Law Commission 'Reform of Offences against the Person, ${ }^{5}$ proposes to reform the law of consent (central to the debate of legality in BDSM), but specifically excludes consent in sexual situations. The report states that 'copious' amounts of academic work has been conducted in the area of consent to sexual acts and it specifically cites several articles as representative of that body of work. It is not just lesbians who make no appearance in the Law Commission's research. Of the four articles cited by the Law Commission, there are zero uses of the word 'gay'; zero uses of the word 'lesbian' and three for 'homosexual'. 6 These are not criticisms, merely observations. There are some exceptions, Ken Plummer's wonderful work, Modern Homosexulities; Fragments of Lesbian and Gay Experience, does include several chapters which focus exclusively or predominantly upon lesbians, although only two of the chapters deal with lesbians existence and sexuality outside of the realm of marriage, families and motherhood. Jeffrey Weeks' important work Coming Out: homosexual politics in Britain from the nineteenth century to the present (Weeks 1979) includes 37 pages on lesbian history.

It might be hoped that if so called 'conventional' textbooks do not address lesbians, perhaps those books which are written from the perspective of women and/ or those that can be labelled feminist would be more inclusive? Works that could legitimately be described as ground-breaking and significant have also failed to devote much space to lesbian issues. In Kate Millett's Sexual Politics, 'lesbianism' appears on two pages (336-337), footnoted and stating rather depressingly that "whatever its potentiality in sexual politics, female homosexuality is currently so

\footnotetext{
4 London: Pluto Press, 1982.

5 Law Commission (2014) Consultation Paper No 217, at page 19. The articles cited are; D Kell, "Social Disutility and Consent" (1994) 14 Oxford Journal of Legal Studies 121; M Giles, "Consensual Harm and the Public Interest" (1994) 57 Modern Law Review 101; N Bamforth, "Sadomasochism and Consent" [1994] Criminal Law Review 661; P Murphy, "Flogging live complainants and dead horses: we may no longer need to be in bondage to Brown" [2011] Criminal Law Review 758.

${ }^{6}$ Giles mentions 'homosexual once' whilst Murphy uses the term twice.
} 
dead an issue that while male homosexuality gains a grudging tolerance, in women the event is observed in scorn or silence." (Millett 1971). Fredman's otherwise important book Women and the Law (Fredman 1998) uses the word 'lesbian' once. Bridgeman and Milns Feminist Perspectives on Law (in all other respects, an excellent book), contains just two references to lesbians in the index and these refer to families and reproductive technology. Carol Smart's Feminism and the Power of Law (Smart 1989) contains two references in the index to 'lesbianism'. Again, there are some exceptions. For example, whilst Hilaire Barnett's Introduction to Feminist Jurisprudence (Barnett 1998), makes a single reference to 'lesbian feminism' in the index, there are 11 incidents where the word 'lesbian' is used in the main text. In Feminist and Queer Theory (Fineman, Jackson and Romero 2009), lesbians receive three mentions in the index (one in relation to motherhood; one in relation to parenting and one in relation to pornography), however lesbians are not discussed qua lesbians apart from a small part of one chapter which discusses them in the context of motherhood and families.

The absence of lesbians from scholarship is not of course limited to academic work. To a large extent, feminist literature generally has similarly consistently failed to incorporate and account for lesbian existence and experiences. Although there are of course scholars who have specifically addressed the partial visibility of lesbians and the representation of lesbians, they have done so whilst recognising that these categories are both contingent and fragile (Rubin 1984). Calhoun for example, has explored the non-recognition of lesbian existence suggesting that feminist studies has failed to capture lesbian difference because it has not "begun with a full-blown theory of heterosexist oppression fully parallel to race and class oppression" (Calhoun 1995: 29). Other studies have set out to deliberately include lesbians; a good example of this is the article by Auchmuty, Jeffreys and Miller who point out that 'even today lesbian history tends to be found in separate monographs ... rather than integrated into more general feminist historical accounts' (Auchmuty et al. 1992: 91). The lack of attention (especially by early) feminist discourse paid to lesbian subjective experience, (largely driven by the myth that one oppressed group cannot in turn oppress another), meant that early feminism centred its discourse on the patriarchal nature of male-female relationships, at the expense of critical examination of the heterosexual imperative. Because early feminism operated on the basis of essentialist meanings of male and female, the only 'path' of resistance was to reverse the present day assumptions, i.e., making women 'superior' to men. The lack of attention paid by much of feminism in the early 1970s to the assumptions and constructions upon which the compulsory nature of heterosexuality rests meant that:

[T]hey risked accepting that being heterosexual was an essential part of their being, and in this way were demonstrably less willing to consider the possibility that sexual orientation is itself a social construct, rendered meaningless if social and ideological punishments and rewards associated with illicit and licit forms of sexual expression were removed (Whelehan 1995: 92). 
In other words, the omission to critically address the construction of a compulsory form of heterosexuality resulted in a failure to examine and thereby expose the ideological and hierarchical construction of sexuality constructed as normatively and exclusively, heterosexual. It is only recently, that 'second wave' feminism has largely left biological determinism behind and turned instead to social constructionism, extending this to the sexual domain. Even so, there still appears to be a continuing lack of attention paid to the impact of the heterosexual imperative. For example, Tong only includes lesbians within a separate discussion of radical feminist thought (Tong 1992). One of the earliest books of feminist history makes only one mention of lesbians (Rowbotham 1973). In contrast, Rich has demonstrated the social construction and enforcement of compulsory heterosexuality (Rich 1980), and observed that the institution of heterosexuality holds sway over all women regardless of their sexual choices-which in fact, have little to do with 'choice' as such. Because of the assumption of a 'normality' deemed to be inherent in heterosexual existence, the socio-legal control over female identity continues. In a variety of ways, lesbians have been socially constructed as 'outsiders' to the law and society and invariably these constructions have been negative (Kitzinger 1987). Thus, there is a need for heterosexual feminists to examine heterosexuality as a political institution which disempowers women-and to change it' (Rich 1980: xii).

The failure to acknowledge lesbian existence matters. It has significant consequences. The disputes that surround sexual behaviour have significant symbolic importance and "often become the vehicles for displacing social anxieties." (Rubin 1999: 143). Law exists to exercise control over individuals or alter their behaviour. As a system of control, it therefore rewards or punishes in accordance with obedience or disobedience to a certain set of rules. The laws relating to unacceptable sexual expression or behaviours are no exception to this. Indeed, concerns surrounding sexual morality are often at the forefront of the law making process. However, as I have suggested above, it is predominantly gay men's sexual expression which has come under the legal gaze. If lesbians do not speak of their erasure from legal discourse and from legal existence, they disappear. Rich sums this up as follows;

Whatever is unnamed, undepicted in images, whatever is omitted from biography, censored in collections of letters, whatever in misnamed as something else, made difficult-to-come-by, whatever is buried in memory by the collapse of meaning under an inadequate or lying language - this will become, not merely unspoken, but unspeakable [emphasis in original] (Rich 1995: 199).

Rich suggests that it is not just invisibility which presents a problem, but that lesbian identity and existence is in danger of becoming unspeakable. However, I wish to take this analysis a little further by suggesting that a police discovery of a lesbian BDSM dungeon and any subsequent trial will render some aspects of lesbian identity distortedly visible and speakable in some aspects, whilst simultaneously continuing to render other aspects of lesbian identity invisible. There is a danger that if the lesbian BDSM dungeon is discovered by law, the legal processes that are 
activated by this discovery (arrest; investigation, charge, prosecution, trial, sentencing), will construct some of the women as being able to give 'real' consent and the others as violent transgressors of the rules of gender performativity and therefore, of criminality. The difference would be determined by those who 'gave' and those who 'received'. It is clear therefore, that the issue of 'genuine' or 'real' consent (Cowan 2012) is an important site of contestation, and it is to this issue that I now turn.

\section{(Lesbian) Consent}

I have argued above that the expression of female sexuality receives different legal attention than does the expression of male sexuality and that women who therefore engage in an activity which to them is sexual, but to law is violence, may very well be subjected to different normative control. Part of this different normative control relates to the issue of consent. I suggest that some of the lesbians in the fictitious BDSM dungeon will be constructed as being able to give 'real' consent, whilst the others will be constructed as violent transgressors of the rules of gender performativity and therefore, of criminality. The crucial difference would be determined by those who 'gave' and those who 'received'. This fictitious lesbian BDSM case would be viewed through the lens of hetero-patriarchy; the masochist would be viewed as performing the 'normal' female submissive role in sexual relations of submission and therefore deemed capable or even expected to give consent, whilst the sadist would be viewed as usurping the role assigned to her by heteropatriarchy and would therefore receive legal opprobrium and condemnation. Indeed, the blogger, writing under the pseudonym Bitchy Jones, (writing Bitchy Jones's Diary), raised similar concerns about the issues of pleasure, desire and consent. The blog was written by a dominatrix who wrote about some of the problems she saw with the wider BDSM community which she was part of (Barker 2013). Bitchy reveals that regardless of whether men or women are dominant or submissive, the women engaging in BDSM are expected to conform to normative ideas of beauty in ways that men are not (Barker 2013: 24). Indeed, Bitchy suggests that the;

$[\mathrm{P}]$ ractices that dominatrices mostly engage with are those that are desired by submissive men rather than those they want themselves. And she argues that the idea of female sexual fluidity reproduces the idea of women responding to men's desires rather than having desires of their own: that their only allowed pleasure is in being desired. She links this to the way in which women who are paid for sex (pro dommes and escorts) have become the cultural role models of what empowered female sexuality should look like, both within and outside her community (Barker 2013: 24).

Unfortunately, the Bitchy Jones no longer blogs for the post. In deciding not to continue with the blog, Bitchy Jones declared that “Kink's broken. I hate it. I don't really want to play. Something inside me does, but that something is trapped inside the meat of me that hates all this fucking pornified, PVC clad, patriarchy eroticising 
bullshit." (Bitchy Jones's Diary 2010). Indeed, as suggested by Dymock, the reason for the discontinuation of the blog was because "kink is not protected from the normalising effects of the commercialisation of sex, it loses a validity and authenticity that it might have otherwise." (Dymock 2012: 55).

At the core of the $R \mathrm{v}$ Brown case was whether or not a person can consent to harm and how far the State should go in limiting that individuals freedom to consent to harm. This is an issue which has been raised in many different cases and areas of law. ${ }^{7}$ At the core of the argument in favour of BDSM is that made by John Stuart Mill who argued that the only purpose;

[F]or which power can be rightfully exercised over any member of a civilised community, against his will, is to prevent harm to others. His own good, either physical or moral, is not a sufficient warrant... Over himself, over his own body and mind, the individual is sovereign (Mill 1859, 1974: 13).

Mills' version of liberty is one that is encouraging of individualism although Mill himself accepts that there is an on-going tension between liberty and authority. In this context then, Mills argument would suggest that if 'real' consent is given, then there should be no state interference or criminal repercussions because there has been no "violation of a person's right to autonomous self-determination" (Weait and Hunter 2010: 243). Assuming that lesbians are "rational, choosing agents" (Cowan 2012: 3), capable of giving 'real' consent, attempts to restrict lesbian BDSM are therefore oppressive. However, Mill also accepted that there may very well be cases where it is legitimate to limit an individual's freedom in their long term interests and in illustrating this point, he gives the example of a person who wants to sell themselves into slavery, arguing that a person should not be permitted to do so because "the principle of freedom cannot require that he should be free not to be free. It is not freedom to be allowed to alienate his freedom" (Mill 1859, 1974: 236). It was within this context that the court in $R v$ Brown argued that the men posed a danger to society and therefore might cause harm to others. In the fictional lesbian dungeon, the State might seek to justify its actions on the basis that there are two legitimate aims to be pursued; firstly to protect those persons who are deemed 'vulnerable' and secondly, to protect the rest of society from those individuals who do not perform their sexual desires within narrowly constructed ideas of appropriate sexual expression. Arguably, all lesbians fall within the category of 'inappropriate' sexual expression, but those lesbians who are dominant within a BDSM context, are more likely to receive negative legal attention than those who are submissive. Since $R v$ Brown, the State has used the concept of "vulnerability as a way of justifying criminalisation" (Cowan 2012). In other words, any restrictions on BDSM can be justified by the State on the basis of upholding its particular vision of (presumed and particular) moral values.

For some, BDSM can only be understood within the broader context of patriarchal social structures which support male authority, and the unequal power

\footnotetext{
7 See for example the Wolfendon Report; 'Report of the Committee on Homosexual Offences and Prostitution', Cmnd 247 (HMSO: London, 1957); the Hart/Devlin debate; H. L. A. Hart, Law Liberty and Morality (Oxford University Press: Oxford, 1968).
} 
relations between men and women. In other words, BDSM sex is 'bad' sex (Rubin 1999), and is primarily motivated by patriarchal power and dominance, not sexual pleasure or desire. Viewed from this perspective, lesbians who participate in BDSM activities are imitating inherently unequal heterosexual sexual practices. For others, the debate centred on the notion that lesbians who engage in BDSM are providing a site of resistance to hetero-patriarchy and the "transgressive opportunities that it provides mean that it enables women (whether lesbian or heterosexual) to assert their sexual agency." (Weait and Hunter 2010: 245). The issues raised by these debates are relevant to the lesbian BDSM dungeon. I favour the idea that lesbians can exercise agency in giving genuine consent, and that as such, lesbian BDSM can provide a site of resistance to dominant hegemony. I suggest here that expressions of lesbian sexuality should, (however manifested), be encouraged as a site of resistance to the ongoing hetero-patriarchal pressure to condemn and stigmatize lesbian sexual pleasures. Within this context therefore, lesbian BDSM gives lesbians a distinct physical presence which refuses to pander to the heterosexual preference for lesbians to remain discreetly invisible (Nestle 1988: 100). Calhoun suggests that contrary to appearance, lesbians who engage in BDSM do not;

[C]onflict with feminist goals, because it substantially differs from heterosexual male-dominant, female-subordinate sexual relations which also eroticize violence. Because lesbians belong to the same sexual caste, lesbian SM occurs outside of the larger frame of gender inegalitarian relations, and because the lesbian masochist consents to and controls the scene, she retains the right to determine what happens to her body (Calhoun 1995: 15).

For some however, Lesbians who take part in BDSM activities can't give 'real' consent to receive because they are subconsciously mimicking the inherently unequal patriarchal and heterosexual practices of dominance and submission. In other words, heterosexual sexual relations are personified by oppression, 'ritualised power differentials' and patriarchal assumptions (O'Sullivan 1999: 99). As argued by MacKinnon, because genders are 'created through the eroticization' of dominance and submission, it is not possible to know whether or not a woman who on the face of it apparently enjoys forced sex or coercion, does so because she has been conditioned by patriarchy to view her sexuality in a masochistic way (MacKinnon 1989).

In this context, discourse analysis would suggest that it is the performance of gender which creates the 'meaning' given to legal and social practices. The work of Jacques Derrida, Michael Foucault and Judith Butler have contributed in significant ways to the analysis of the importance of discourse analysis. Within this poststructuralist context, women and men are 'regarded as constructions or representations, achieved through discourse, performance and repetition rather than being 'real' entities' (Pilcher and Whelehan 2004: xii). Butler's conception of gender is perhaps the most radical of all, taking as she does a Foucauldian model, and asserting that all identity categories "are in fact the effects of institutions, practices, discourses with multiple and diffuse points of origin" (Butler 1990: ix). Whilst it may be relatively simple on the face of it to agree with John Stuart Mill's 'no harm' principle (discussed above), this presupposes a genuine equality between the 
participants. Feminist discourse analysis suggests that the performance of gender roles is constructed to engender a societal and legal inequality as between males and females (Butler 1990). Consequently therefore, where inequality exists, any BDSM activity is performed through this lens of inequality and there is therefore no 'real' or genuine consent. However, do the same or similar considerations apply when discussing BDSM between lesbians as opposed to BDSM when practices between heterosexuals? If gender identity is constructed through the prism of heteronormative patriarchy, then it is logical that the answer to this question is 'yes'. I submit that it is extremely problematic to claim that lesbian BDSM successfully resists heteronormative and patriarchal imperatives for the sole reason that the participants are lesbians. Being a lesbian does not in and of itself release one from the dominant social and legal constructions of gender performativity, although it may very well provide a potential site of and for, resistance to these ideological and practical norms.

Many authors (Linden et al 1982) commonly take a position that one cannot be both a sadomasochist and a feminist. The term lesbian sadomasochist is therefore a contradiction in terms. Lesbians who take part in BDSM activities are therefore copying inherently unequal heterosexual practices and perpetuating the "values of the patriarchal ruling class, whose stock-in-trade is dominance and submission" (Meredith 1982: 97). Indeed, heterosexual desire can still be found in lesbian relationships because heterosexual oppression will still be present even where another gender is absent "otherness can be reintroduced ... through the practice of sadomasochism or role playing." (Jeffreys 1990: 301). In particular, lesbian BDSM represents a 'false consciousness' representing an "internalization of a homophobic heterosexual view of lesbians." (Russell 1982: 176). Sexuality is not immune to these forces. Thus sexual expression has been constructed by hetero-patriarchy. As Phelps succinctly argues;

[S]o all-pervasive is the male bias of our culture that we seldom notice that the fantasies we take in, the images that describe to us how to act, are male fantasies about females. In a male world, female sex is from the beginning unable to get a clear picture of itself (Phelps 1972: 13).

It is clear therefore that the issue of consent is a problematic concept. For some, since there is mutual consent, there is no problem; consenting adults engaging in truly consenting sexual activity should be of no interest to society or to law (Thorn 2012 and Hornsby 1999). Supposing for a brief moment that lesbians were capable of giving 'real' consent to BDSM; this, in and of itself does not mean that it is not oppressive. There are many women for example who have consented to be married to a man and whilst these women might argue that they were able to give 'real' consent to the marriage, this does not mean that marriage is non-oppressive. The consent given in lesbian BDSM does not necessarily or automatically mean that the heterosexual power dynamics have been overcome (Butler 1982). However, as Rubin points out BDSM is not an obvious site at which the possibility of consent has been compromised (Rubin 1987: 224). 
A post-structuralist approach for example, would argue that all meanings associated with identities or sexual practices are the result of social and legal construction in a complex dialectical way.

\section{Conclusion}

In the light of these concerns therefore, I suggest that a way forward is to steer a path through both 'sides' of the argument through a successful overlapping of poststructuralism and liberalism. Part of this solution lies in an adaptation of Plummer's call for "notions of national citizenship". 8 Sometimes, "particular groups with sharply defined boundaries' are necessary (Wolfe 1992: 311-312). Given this, the criminal law should not only seek to acknowledge the existence of lesbians, but strive to do so outside of the category of 'lesbianandgaymen'. Further, the criminal law needs to carefully consider whether there can be 'real' consent in lesbian BDSM cases and give consideration to the unequal distribution of power. These considerations should rightly be of significant and legitimate concern to the state. Whilst I have great sympathy for the argument that lesbian BDSM is driven by heteronormative and patriarchal concerns, I do not think that this justifies the notion that limits should exist in law in which the activities of lesbian BDSM practices are constrained because these choices are not 'real' but instead shaped by heteropatriarchal normativity. As I have suggested above, if there were to be case of lesbian BDSM that was prosecuted in the courts, my suggestion is that it would be the sadist rather than the masochist which would attract attention. Viewed through the lens of hetero-patriarchy, the masochist would be viewed as performing the 'normal' female submissive role in sexual relations (reflecting the disappointing amount of times I still get asked 'which one of you is the man?'). The sadist on the other hand is more likely to attract legal opprobrium and condemnation, usurping as she does her allocated role of submissive; to be dominant and in control is not the role that hetero-patriarchy has assigned to her.

Whilst there has been some progression in terms of legal sexual morality, there have also been retrograde steps taken in this area. There should be significant concerns over the new regulations that came into force on 1st December 2014. The Audiovisual Media Services Regulations 2014 amends the 2003 Communications Act and applies to content created in the UK. The content of all Video on Demand (VoD) services is no longer permissible if it cannot be classified as an R18, according to guidelines laid out by the British Board of Film Censors (BBFC). There is a significantly long list of sexual activities that will now fall foul of these guidelines. These include; spanking; caning; aggressive whipping; penetration by any object 'associated with violence'; physical or verbal abuse (regardless if consensual); urolagnia; female ejaculation; strangulation; facesitting and fisting. If female ejaculation on video is now a criminal offence, it is not difficult to see how this will impact upon lesbians who film the BDSM they are engaging in. There is, of course no ban on the portrayal of male ejaculation, and there does not appear to be a

\footnotetext{
${ }^{8}$ See also Chatterjee (2012).
} 
reason given for this. The portrayal of female sexual pleasure has been officially outlawed. A further concern is scoping exercise that he Law Commission has been asked to carry out by The Ministry of Justice as a first step towards a potential project to reform the law on offences against the person. They have made it clear however, that that the law relating to consent will not be looked at, stating that;

The law concerning the effect of consent on liability for crimes of violence is extremely complicated and is the subject of a copious academic literature. ...

[W] are not proposing to reform the general principles governing consent in this project (Law Commission 2014: paragraph 2.55).

This article has argued that lesbian identity in particular, continues to be regarded and rendered 'the Other' and 'the invisible', in relation to its position in the network of heterosexual legal and social power relations. This is even more so within the context of BDSM. It is important to resist the intrusions of heteropatriarchal power and embrace the existence of a lesbian identity, albeit one that is constantly in flux. Resistance to the criminal censure and societal condemnation of BDSM can "offer important opportunities for gaining visibility and empowerment". It is only by such resistance can the lesbian subject exist. In order for this resistance to happen, the lesbian must, by necessity exist as a discursive epistemological subject. However, I suggest that this has to happen without placing reliance upon essentialist notions of the knowable subject. There needs to be recognition that there is no discursive 'knowable' lesbian essence, but additionally, it also needs to be understood that there can be pluralities of existence. Whilst essentialism can offer sites of resistance to dominant hegemony, it has an unattractive claim to the universal subject. Poststructuralism claims to offer a refutation of that dominant hegemony, but denies the subject.

Open Access This article is distributed under the terms of the Creative Commons Attribution 4.0 International License (http://creativecommons.org/licenses/by/4.0/), which permits unrestricted use, distribution, and reproduction in any medium, provided you give appropriate credit to the original author(s) and the source, provide a link to the Creative Commons license, and indicate if changes were made.

\section{References}

Allen, M. 2013. Textbook on criminal law, 12th ed. Oxford: Oxford University Press.

Auchmuty, R., Jeffreys, S., and E. Miller. 1992. Lesbian history and gay studies: Keeping a feminist perspective. Women's History Review 1(1):89-108.

Barnett, H. 1998. Introduction to Feminist Jurisprudence. New York: Cavendish Publishing Limited.

Barker, Meg. 2013. Gender and BDSM revisited: Reflections on a decade of researching kink communities. Psychology of Women Section Review. 15(2):20-28.

Bell, D., and G. Valentine. 1995. Mapping desire. Geographies of sexualities. London: Routledge.

Bitchy Jones's Diary, posted 1 February 2010, post entitled 'Some Kind of Climax'. Retrieved from http://bitchyjones.wprdpress.com.

Boryczka, J.M. 2012. Suspect citizens: Women, virtue, and vice in backlash politics. Philadelphia, PA: Temple University Press.

Butler, J. 1982. Lesbian S \& m: The politics of dis-illusion. In Against sado-masochism: A radical feminist analysis, ed. Robin R. Linden, et al., 168-175. East Palo Alto, CA: Frog in the Well.

Butler, J. 1990. Gender trouble. New York: Routledge. 
Calhoun, C. 1995. The gender closet: Lesbian disappearance under the sign "woman". Feminist Studies. 21(1): 7-34.

Chatterjee, B. 2012. Pay v UK, the probation service and consensual BDSM sexual citizenship. Sexualities 15(5-6): 739-757.

Cowan, S. 2012. To buy or not to buy? Vulnerability and the criminalisation of commercial BDSM. Feminist Legal Studies 20(3):263-279.

Deckha, M. 2007. Pain, pleasure, and consenting women: Exploring feminist responses to S/m and its legal regulation in Canada through Jelinek's the piano teacher. Harvard Journal of Law \& Gender 30(2): 425-459.

de Than, Claire, and R. Heaton. 2013. Criminal law. Oxford: Oxford University Press.

Donoghue, E. 1993. Passions between women: British Lesbian culture, 1668-1801. London: Scarlet Press.

Dymock, Alex. 2012. But femsub is broken too! On the normalisation of BDSM and the problem of pleasure. Psychology \& Sexuality 3(1):54-68.

Faderman, L. 1985. Surpassing the love of men: Romantic friendship and love between women from the renaissance to the present. London: The Women's Press.

Fineman, M.A., J. Jackson, and A. Romero. 2009. Feminist and queer legal theory: Intimate encounters, uncomfortable conversations. Aldershot: Ashgate.

Fredman, S. 1998. Women and the law. Oxford: Oxford University Press.

Frye, M. 1983. To be and be seen: The politics of reality. In The politics of reality: Essays in feminist theory. Freedom, CA: Crossing Press.

Giles, M. 1994. R v Brown: Consensual harm and the public interest. Modern Law Review 57: 101.

Hall, S. 1996. Introduction: Who needs identity? In Questions of cultural identity, ed. S. Hall, and P. Gay. London: Sage.

Herring, J. 2013. Criminal law London: Palgrave Macmillan Law Masters.

Herring, J. 2014. Criminal law: Text, cases, and materials, 6th ed. Oxford: Oxford University Press.

Hoople, T. 1996. Conflicting visions: SM feminism, and the law. A problem of representation. Canadian Journal of Law Society 11: 177.

Hornsby, T. 1999. Gender role reversal and the violated lesbian body: Toward a feminist hermeneutic of lesbian sadomasochism. Journal of Lesbian Studies 3(3): 61-72.

Hornsby, T.J. 2008. Gender role reversal and the violated lesbian body: Toward a feminist hermeneutic of lesbian sadomasochism. Journal of Lesbian Studies 3(3):61-72.

Jeffreys, S. 1990. Anticlimax. London: The Women's Press.

Kitzinger, C. 1987. The social construction of lesbianism. London: Sage.

Law Commission. 2014. Reform of offences against the person: A scoping consultation paper. Consultation paper no. 217.

Linden, Robin Ruth, Darlene R. Pagano, Diana E.H. Russell, and Susan Leigh Star (eds.). 1982. Against sadomasochism: A radical feminist analysis. East Palo Alto, CA: Frog in the Well.

MacKinnon, C. 1989. Toward a feminist theory of the state. Cambridge, MA: Harvard University Press.

Meredith, J. 1982. A response to Samois. In Against sadomasochism: A radical feminist analysis, ed. Robin Ruth Linden. San Francisco: Frog in the Well.

Mill, J.S. 1859. On liberty (Collins: London, 1974). Cambridge: Cambridge University Press.

Millett, K. 1971. Sexual politics. London: Rupert Hart-Davies Ltd.

Moran, L. 1996. The homosexual(ity) of law. London: Routledge.

Murphy, T. (ed.). 2000. Reader's guide to lesbian and gay studies. London, New York: Routledge.

Nestle, J. 1988. In a restricted country. London: Sheba Press.

O'Sullivan, S. 1999. What a difference a decade makes: Coming to power and the second coming. Feminist Review 61:97-126.

Ormerod, D. 2011. Smith and Hogan's criminal law, 13th ed. Oxford: Oxford University Press.

Phelps, L. 1972. Female sexual alienation. Woman: A Journal of Liberation 3(1):13-18.

Pilcher, J., and I. Whelehan. 2004. 50 Key concepts in gender studies. Thousand Oaks, CA: Sage.

Plummer, K. (ed.). 1992. Modern homosexualities: Fragments of lesbian and gay experiences. London: Routledge.

Plummer, K. 2002. Sexualities: Sexualities and their futures. London: Routledge.

Rich, A. 1980. Compulsory heterosexuality and lesbian existence. Signs 5(4).

Rich, A. 1995. On lies, secrets, and silence: Selected prose, 1966-1978. New York City: W. W. Norton \& Company, Reissue edition. 
Rowbotham, Sheila. 1973. Hidden from History: 300 years of women's oppression and the fight against it. London: Pluto Press.

Rubin, G. 1984. Thinking sex: Notes for a radical theory of the politics of sexuality. In Pleasure and Danger: Exploring female sexuality, ed. C. Vance, 267-319. London: Routledge \& Kegan Paul.

Rubin, G. 1987. The leather menace: Comments on politics and S/M. In Coming to power: Writings and graphics on Lesbian S/M. Boston: Alyson Publications.

Rubin, G. 1999. Thinking sex: Notes for a radical theory of the politics of sexuality. In Culture, Society and Sexuality, a Reader, ed. R. Abelove, and P. Aggleton. London: UCL Press.

Russell, D.E.H. 1982. Sadomasochism: A contra-feminist activity. In Against sadomasochism: A radical feminist analysis, ed. Robin Ruth Linden. San Francisco: Frog in the Well.

Sedgwick, E.K. 1990. Epistemology of the Closet. Berkeley and Los. Angeles: University of California Press.

Seidman, S., N. Fischer, and C. Meeks (eds.). 2006. Handbook of the new sexuality studies. New York: Routledge International Handbooks.

Shadmi, E. 2008. The construction of lesbianism as nonissue in Israel. In Postzionism: A reader, ed. Laurence Jay Silberstein. New Brunswick, NJ: Rutgers University Press.

Simester, A., and J. Spencer. 2013. Simester and Sullivan's Criminal Law: theory and doctrine, 5th ed. Oxford: Hart Publishing.

Smart, C. 1989. Feminism and the power of law. London: Routledge.

Smith, A.M. 1992. Resisting the erasure of lesbian sexuality: A challenge for queer activism. In Modern homosexualities: Fragments of lesbian and gay experiences, ed. Ken Plummer. London: Routledge.

Smyth, C. 1990. The pleasure threshold: Looking at lesbian pornography on film. Feminist Review. 34: $152-159$.

Stychin, C. 1995. Law's desire: Sexuality and the limits of justice. New York: Routledge.

Thompson, J.M. 2002. Mommy queerest: Contemporary rhetorics of lesbian maternal identity. Amherst and Boston: University of Massachusetts Press.

Tong, R. 1992. Feminist thought: A comprehensive introduction. London: Routledge.

Thorn, Clarisse. 2012. The S\&M feminist. Seattle/North Charleston: CreateSpace Independent Publishing Platform.

Weait, M. and Hunter, R. 2010. Commentary on $R v$ Brown. In Feminist judgments: From theory to practice, ed. Rosemary Hunter, Clare McGlynn and Erika Rackley. Oxford: Hart Publishing.

Weeks, J. 1979. Coming out: Homosexual politics in Britain from the nineteenth century to the present. London: Quartet Books.

Weeks, J. 1992. Changing sexual and personal values in the age of AIDS. Paper presented at the forum on sexuality conference, sexual cultures in Europe, Amsterdam, June, at 3, cited in Bell and Valentine. Mapping desire: Geographies of sexualities. London: Routledge.

Whelehan, I. 1995. Modern feminist thought: From the second wave to 'post-feminism'. Edinburgh: Edinburgh University Press.

Wolfe, A. 1992. Democracy versus sociology: Boundaries and their political consequences. In Cultivating differences: Symbolic boundaries and the making of inequality, ed. Michele Lamont, and Marcel Fournier. Chicago: University of Chicago press.

Wood, Nigel, and David Lodge. 2013. Modern criticism and theory: A reader. London: Routledge.

Zimmerman, B. (ed.). 2000. Encyclopaedia of lesbian histories and cultures. London: Taylor \& Francis. 